\title{
A Community Public Service Capstone Engineering Design Project: A Collapsible Ramp for an Electric Cart/Wheelchair
}

\author{
Kenneth E. Siegenthaler and \\ Erik C. Bowman \\ Department of Astronautics \\ United States Air Force Academy
}

\begin{abstract}
A capstone engineering design and construction course, required for graduation at the United States Air Force Academy, has often involved community service projects. One such project was the design and construction by students of a collapsible electric cart/wheelchair ramp for a handicapped woman who liked to travel on the airlines. The design constraints required cadets to perform extensive research and development to produce an efficient design using lightweight materials. Some of the constraints included a maximum weight of 70 pounds and a minimum extended length of 11 feet. The ramp had to fold up into a single unit that qualifies as checked baggage on the airlines. The motivational value of a public service project for a handicapped person was a major factor in developing a positive mental attitude by a team of non-science and engineering majors. The program required the student team to meet all of the Department of Defense milestones, including Alternative System Review (ASR), Proposal Submission, Preliminary Design Review (PDR), Critical Design Review (CDR), and Product Acceptance Demonstration (PAD). This paper discusses the challenges and benefits of such community service projects for satisfying the requirements of a capstone design course for non-science and engineering majors.
\end{abstract}

\section{Introduction}

Community service projects performed by educational institutions have several advantages. A very worthwhile public service is rendered. The students are made more aware of people in need. The students feel they have done something worthwhile. The person or persons helped feel better about society's caring for people in need. Such a project increases the interaction of the educational institution with the "real world". The students apply their textbook learning to real-world problems and realize that solving real problems is not as easy as punching numbers into a calculator. This paper discusses the 
challenges and benefits of community service projects for satisfying the requirements of a capstone design course for non-science and engineering majors.

\section{The Electric Cart/Wheelchair Project}

A capstone engineering design and construction course, required for graduation at the United States Air Force Academy, has often involved community service projects.

Engineering Systems Design was the course title. One such project was the design and fabrication by students of a collapsible electric cart/wheelchair ramp for a handicapped woman who liked to travel on the airlines. See Figure 1. Her goal was to be able to take

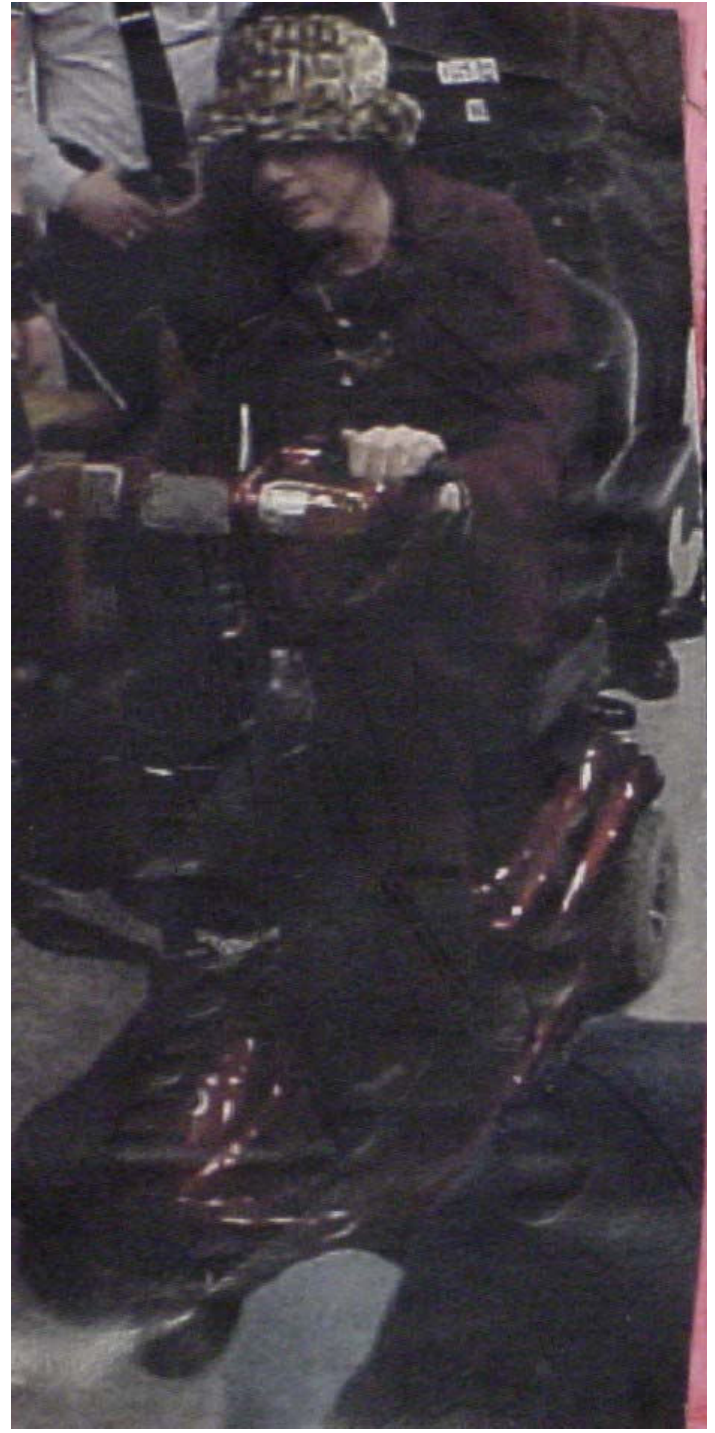

Figure 1. Lady on Electric Cart

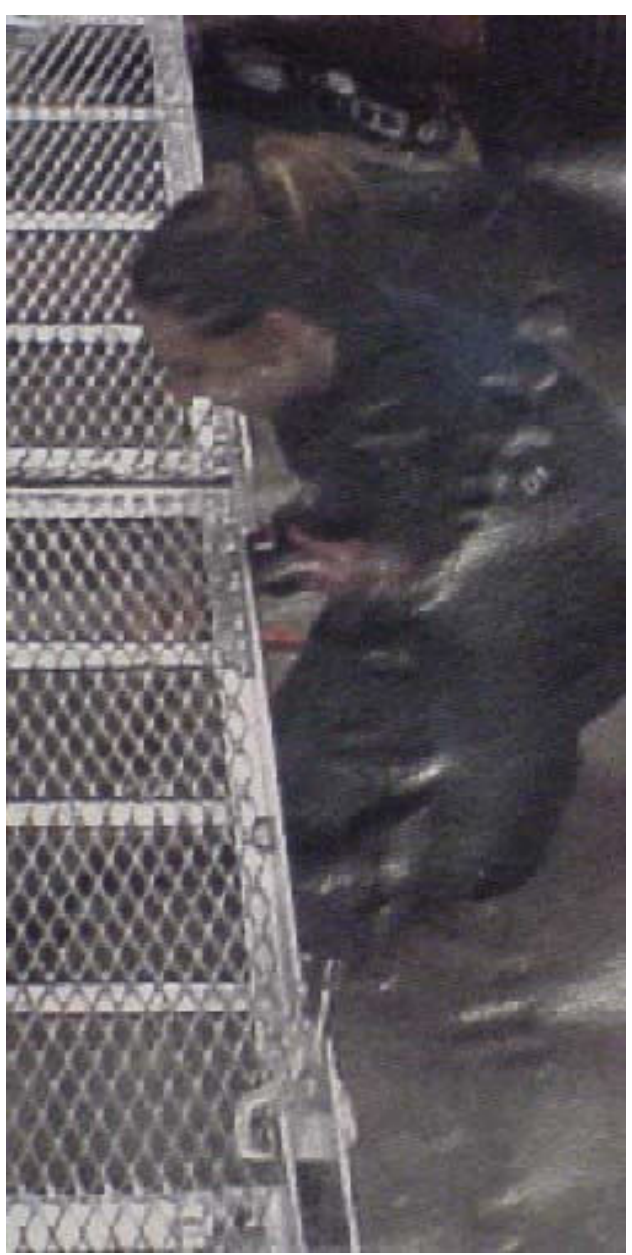

Figure 2. The Ramp 
this ramp with her on the airplane as checked baggage. When she arrived at her destination she would rent a pickup and use the ramp to drive her electric cart up into the pickup. Although there are many ramp designs for driving carts into vehicles, the challenge for this project was to make the ramp acceptable as checked baggage on an airline. The design constraints of this ramp required cadets to perform extensive research and development to produce an efficient design using lightweight materials. Some of the constraints included a maximum weight of 70 pounds and a minimum extended length of 11 feet. The ramp had to fold up into a single unit that qualified as checked baggage on the airlines. The motivational value of a public service project for a handicapped person was a major factor in developing a positive mental attitude.

\section{The Statement of Work (SOW)}

The Statement of Work (SOW) is the bible of the project. It is the reason for doing the work. It outlines the mission. The purpose of the SOW is to define the tasks to be accomplished by the contractor during the contract period[1]. The SOW is where all of the specifications of the deliverable are spelled out, as well as the timetable the program must satisfy. In this class the contractor was a "company" formed by the cadets in the class. The duration of the contract was the semester of the course. The complete SOW is in Appendix A. The SOW for this class was made as close to the actual situation in government contracting as possible.

\section{Design Challenges}

The primary design problems were weight and size. Size was driven down by the airlines and up by the fact that the electric cart had cutoff switches just behind the rear wheels that were very close to the ground to prevent the electric cart from doing a "wheelie". This meant that if the cart started up a very steep angle, the cutoff switches cut off the power to the cart. Therefore, the angle of the ramp had to be shallow (less than 15 degrees), which required a longer ramp to reach into the back of a pickup truck. Since the ramp was 11 feet long, the airlines also required that the ramp must fold to a shorter length. This requirement dictated a hinged system, because breaking the ramp into individual pieces would require more checked baggage and more likelihood of lost parts. All of these considerations drove up the weight of the ramp, but the airlines limits checked baggage to 70 pounds. This dictated lightweight construction. Obviously safety dictated strong construction. Because the program was to be completed on a minimum budget, exotic lightweight materials were not an option. All of these factors made this a valuable project because it had so many similarities to aircraft design and fabrication.

\section{The Program Structure}

The program required the student team to meet all of the Department of Defense milestones, including Alternative System Review (ASR), Proposal Submission, Preliminary Design Review (PDR), Critical Design Review (CDR), and Product Acceptance Demonstration (PAD). The instructor was the government program manager. The cadets in the class were treated as a contractor performing work on a

\footnotetext{
"Proceedings of the 2004 American Society for Engineering Education Annual Conference \& Exposition Copyright @2004, American Society for Engineering Education"
} 
government contract. A Senior Reviewing Official (SRO) was an experienced senior individual from outside of the department who served as a senior independent reviewer of the contract[1,2].

The Alternative System Review was an informal briefing. The purpose of the briefing was to provide a forum, before the proposal, to present and evaluate the cadet contractor's approach to the technical design problem. Upon successful completion of this briefing, the cadet contractor was allowed to proceed with the proposal preparation.

The purpose of the proposal was to define the cadet contractor's overall approach to the technical, management and cost aspects of the project. The proposal had to be a complete description of how the cadet contractor would fulfill the requirement of the Statement of Work (SOW). It represented a commitment by the cadet contractor for the work to be accomplished over the course of the semester. The proposal was a general description of how a given design would be developed through studies, analysis, fabrication, and testing. There were penalties or bonuses in the grading for being late or early on meeting the milestones in the project. Before the cadet contractor could perform the Preliminary Design Review (PDR), they had to submit an Engineering Analysis Package (EAP) describing the analysis performed by the cadet contractor to ensure the project would work and meet the project requirements. The EAP was to show the design works "on paper" and thus maximize the probability of success.

The Preliminary Design Review (PDR) was a formal briefing with the objective of gaining permission to proceed with the fabrication and test of subsystems. The PDR gave the instructor and Senior Reviewing Officer an opportunity to evaluate the cadet contractor's research. The cadets were not allowed to acquire materials or begin fabrication until all action items were closed from the PDR. This review forced the cadets to have a detailed and well thought out design before committing funds and effort to fabrication and testing of subsystems. The introduction of the importance of cost was a shock to cadets who were used to using the textbook solution. This restraint was a very maturing process for many of the cadets and introduced them to the importance of maintaining good relationships with the management side of the program. It also introduced them to the complexity of a program and the tremendous responsibilities and pressures on a program manager. They thus came to appreciate the problem of producing a successful program under budget and on time.

The Critical Design Review (CDR) was a formal briefing to the instructor and the SRO, with most of the approving authority resting with the SRO. The objective of the CDR was to gain permission to proceed with the integration of all subsystems and the performance of operational/field testing of the total system. This requirement amounted to an oral examination of the project. Just as you really learn a subject when you are required to teach it, being subjected to questions by the instructor and SRO throughout the student's briefing, stimulated increased understanding of the subject by the cadets.

The Prototype Acceptance Demonstration (PAD) demonstrated and verified the actual performance of the ramp. This was performed by taking the ramp to the home of the

"Proceedings of the 2004 American Society for Engineering Education Annual Conference \& Exposition Copyright C2004, American Society for Engineering Education" 
handicapped individual and driving her electric cart into the back of their family pickup truck. This was the high point of the project for the cadets and the instructor. The family was very appreciative of the convenience and increased mobility the ramp allowed their mother/wife, and brought home to the cadets the true value of community projects.

At the end of the semester, a formal final briefing given to the instructor and SRO served as the final report by a government contractor.[1,2]

\section{The Ramp}

Although the original SOW required the ramp to weigh 30 pounds or less, this was soon modified to the 70-pound limit of checked baggage on an airline. The cadets soon realized that the only way they could meet the 30 -pound requirement was to use very expensive lightweight high-strength materials, such as graphite epoxy. These very expensive materials far exceeded the budget. Aluminum alloys were the only practical materials solution. Because of the previously discussed cutoff safety switches behind the rear wheels, the ramp had to be longer than originally planned. The cadets responded very well to the additional challenges as they appeared. They demonstrated great patience and ingenuity in developing a strong light-weight design that met all of the requirements of the SOW. Perforated materials were used everywhere possible, without sacrificing safety. See Figure 2. Because the weight was now heavier, the design needed a built-in handle and wheels so the folded package could be pulled along like a large suitcase. Except for welding, all of the activities required to take this project from conception to delivering a finished product, were performed by cadets. To make sure the ramp did not slide off of the pickup truck bed while the cart was driving up the ramp, "paws" or pads where attached to the top of the ramp to grip the truck bed. Nylon straps to fasten the ramp to the truck bed were also used. See Figures 3 and 4 . The problem of a rigid extension at the hinge was solved by beefing up the main supports of the bridge in the hinge area and using a pin which was welded to a cable, which in turn was welded to the ramp frame so it would not be lost.

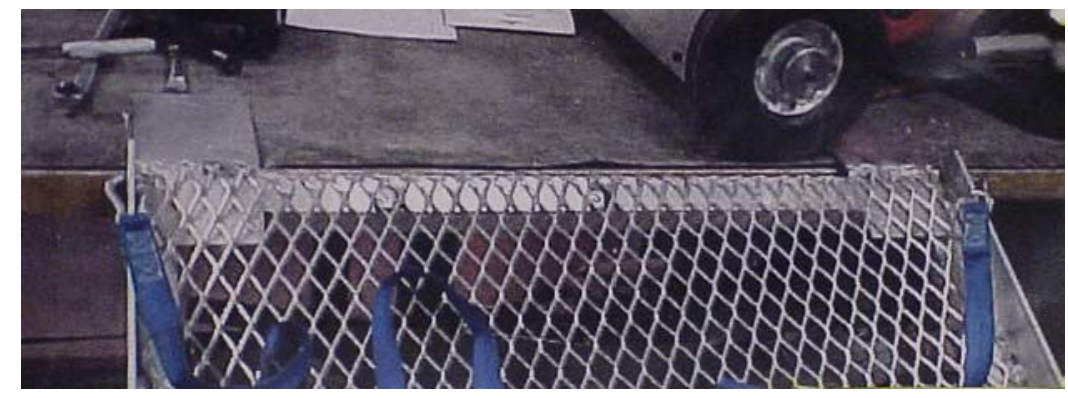

Figure 3. The Ramp with the "Paws" of the Pads Lying Flat on the Truck Bed. The Nylon Straps are to be Fastened in the Forward Stake Pockets or Side Rails in the Truck 


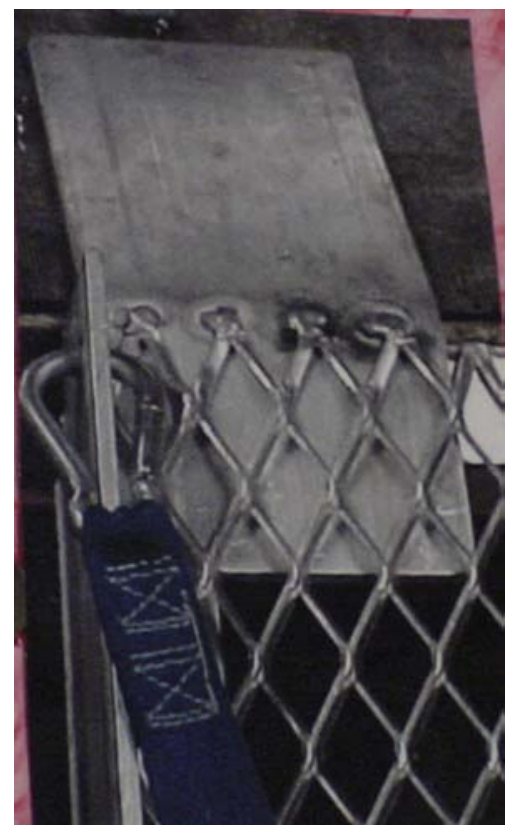

Figure 4. A Detailed View of the "Paws" or Pads that Help Connect the Upper End of the Ramp to the Truck Bed.

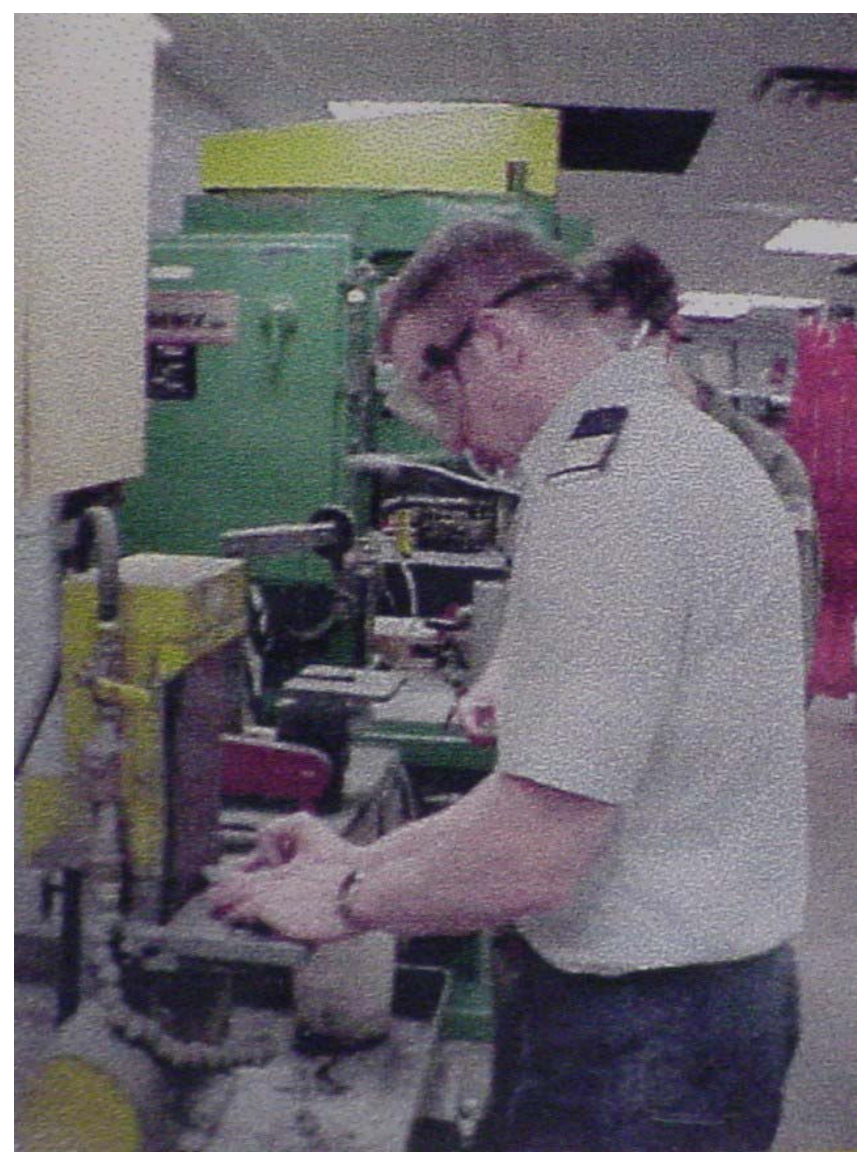

Figure 5. Cadet Sanding and Shaping Parts of the Ramp.

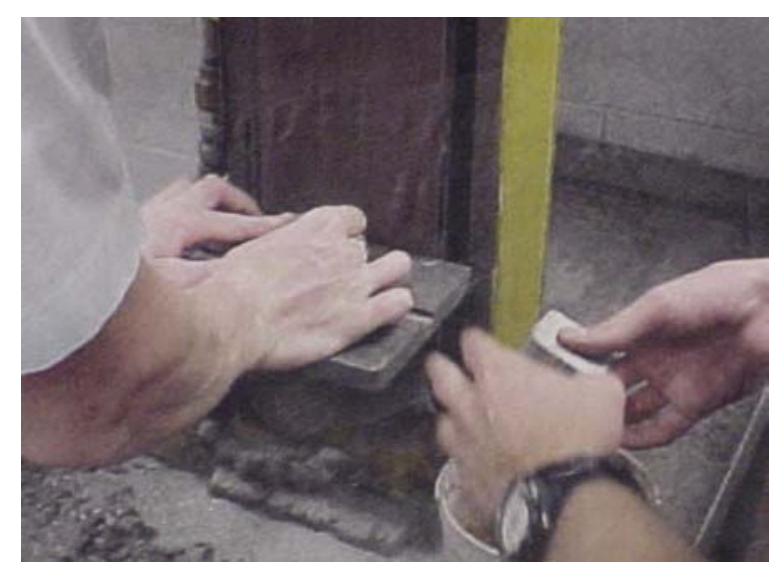

Figure 6. More Hand Work Making Parts for the Ramp 


\section{Cadet Response and Conclusions}

The cadet response to this community project was very positive. The results of the course critiques by the team in this class are presented in detail in Appendix B. This team of 18 cadets rated all aspects of the class higher than the average for all of the other 25 teams in this capstone engineering course. What is more interesting is that this team rated most categories higher than the average of all courses at the Air Force Academy. The value of doing worthwhile community projects in academic courses cannot be overemphasized. It does make a difference to be doing something that makes a difference.

\section{Acknowledgements}

The authors would like to acknowledge the hard work of the cadets and all of the laboratory support personnel that made this project a success. In particular, the dedication to the success of this project of Mr. Jim Arnold, SSgt Timothy Olson and TSgt Lynne Maes is greatly appreciated. If you enjoyed reading this paper, credit our editors, Dr. Fred Kiley and Ms. Lynnette Kaffine.

\section{Bibliography}

1. Bloom, Roland J., and Vallado, David A., Engineering Systems Design, $8^{\text {th }}$ ed., edited by Elsa S. Bruno and Erik C. Bowman, Department of Astronautics, United States Air Force Academy, CO, 2000.

2. Bowman, Erik C., Engineering 410 Instructor Book, Department of Astronautics, United States Air Force Academy, CO, 2001.

\section{Biographies}

KENNETH E. SIEGENTHALER is an Associate Professor of Astronautics at the U.S. Air Force Academy. Dr. Siegenthaler has a B.S in the Arts \& Sciences from the U.S. Military Academy, a B.S. in Physics from the University of Utah, and a M.S. and a Ph.D. in Engineering Physics from the Air Force Institute of Technology. He is a registered Professional Engineer in the state of Colorado.

ERIK C. BOWMAN is an active-duty Major in the U.S. Air Force, and served as an Assistant Professor of Astronautics at the U.S. Air Force Academy. Major Bowman has a B.S. from the U.S. Air Force Academy and a M.S. from Purdue University. He served as Course Director for the Engineering Systems Design course. Major Bowman is presently assigned to U.S. Air Force Space Command. 


\title{
APPENDIX A \\ STATEMENT OF WORK \\ (SOW)
}

\author{
Statement of Work (SOW) \\ Portable Electric Cart Ramp
}

\subsection{GENERAL BACKGROUND}

2.1 BACKGROUND. Ms Nancy MeGregor is a military spouse living on the USAF Academy who depends on a wheelchair or a 3-wheeled electric cart for her mobility over longer distances. As she puts it, "I can move and get around fine, but I can't walk far." She is quite independent and often travels alone on airlines. At her destination she mobility cart, rent a preet and assist her, but what she would prefer is to rent an electric mobility cart, rent a pickup truck, and then haul the cart to her destimation in the back of the pickup. However, to accomplish this she needs a portable ramp that would attach to the back of a pickup truck and allow her to safely drive the cart onto and down from the bed of the truck. The ramp would need to be easy to set up and would need to be about the size and weight of a full suitcase when stowed so it could be checked as baggage on

2.2 CONTRACT OFFER. The govermment is offering a contract to design, build, test, and deliver one strong, lightweight, collapsible ramp for safely loading and unloading a 3-wheeled electric mobility cart to and from the bed of a pickup truck. There is $\$ 100$ available to the contractor from the IMPAC fund, $\$ 200$ in materials available from the Engincering $410 \mathrm{lab}$, and $\$ 250$ in materials available from Training Devices. The $\$ 250$ from Training Devices is available ONLY if the contractor MUST hire Training Devices as a subcontractor to do some of the work (most, if not ell, of the constnetion shall be accomplished by the contractor). Also, an unspecified dollar amount may be available

2.3 POINTS OF CONTACT. Points of eontact for this project are:

Maj Mark Malone, government procuring officer, 333-7363 (Wk), 282-3921 (Hm)

Ms Nancy McGregor, customer (user), 472-6855

\subsection{SYSTEM PERFORMANCE REQUIREMENTS}

\section{3,1 GENERAL TECHNICAL REQUIREMENTS}

3.3.1.1 The contractor shail design, build, test, and deliver to Ms Nancy McGregor a strong, lightweight, collapsible ramp for safely driving a 3-wheeled electric mobility cart onto and off from the bed of a standard size pickup truck (see paragraph 3.3.2.8 below). Until ready for delivery to the user, components of the ramp shall be stoted in the Engr 410 lab.

3.3.1.2 Bidders Meeting -- the contractor shall meet with the user before Lesson 5 to regolve any unanswered questions from this statement of work. Any conflicts between the user's needs and the statement of work 
will be presented to the government during the bidders meeting on Lesson
5. Any changes to the reguirements 5. Any changes to the tequirements resulting from this bidders meeting goworment in writing.

3.3.1.3 Subcontractor Labor -- the government expects that the contractor shall possess sufficiont talent to perform all fabrication, testing, and representative must apd in this statement of work. The government Devices or conmercial support) prion to execting (use of USAFA Training normally be obtained only after the to execution. Approval will justification based ung after the contractor shows convincing other benefit to the upon impred performance, substantial savings, or obtained commercially witl govemments and minor components may be contractor design assels must be aprovet approval. The use of non-

faculty. Purchase of a must be approved, including USAFA cadets and requirements of this contract.

3.3.1.4 Safety -- The contractor shall ensure the product meets atl applicable safety codes. The contractor is responsible for researching all of the applicable materials and construction practices for safety issues, and brief the results of their tesearch at the Alterthative Systems Reviow

3.3. 1.4.1 When the ramp is installed and ready to use, it shall bc self supporting and stable enough to carry the design loads and still ailow for reasonable, incidental contact by adults without collapsing, falling,
tipping, or coming apart accidentally.

3.3.1.4,2 The ramp shall be free of any sharp odges, splintered surfaces, pinching hazards, or tripping hazards. This requirement applies during assembly, disassembly, or while installed and in use.

3.3.1.4.3 The contractor shall consider, in coordination with the user and applicable safoty and ADA requirements, whether or not guardrails for the ramp are warranted, and if so, shall provide them.

3.3.1.5 Appearance and Workmanship -- The finished product shall bave a professional appearanee and possess quality workmanship worthy of an Air Force Acadeny project.

3.3.1.6 Hold Harmless Agreement -- The contractor shall ensure a "Holl liarmless Agreement" is signed by Ms Nancy MeGregor prior to, and as a condition of, delivery of the finjshed product. The hold harmless agreement releases the Air Force of any liability resulting from the use of the ramp. 


\subsubsection{Documentation}

3.3.1.7.1 To reduce copying and to aid in the communication of information botween company members and the government, all electronic information prepared for this contract shall be stored on the network in the directory:

"k:lCampushdf drashe4 10hspring2001 4SectionFolderstT6B - DFCF",

Use of email is also encouraged as a means of notifying the government of mectings, project progress and absencos from scheduled company meetings (i.e. class).

3.3.1.7.2 The contractor shall provide to the customer, after revicw by the govemment, a cousolidated User's Manual for this Portabic Electric Cart Ramp. The manual shall provide detailed instructions for assembly, disassembly, storage, and transportation of the ramp, and inchude all recommended user maintenance, a complete parts listing and technical drawings for the structure, specifications for the parts, sources of supply, and the cost for all parts. Also, see paragraph 3,3,1.8.1 below.

3.3.1.8 Public Affairs -- The contractor shall work through the USAFA pubilic affairs Media Relations office to determine the proper means of communicating the progress of the project to the media. The contractor shall draft a joint press release for the combined projects and present it to the government representative. Upon approyal of the ENGR 410 course director, the user, and the government representatives, the contractor shall initiate a press release explaining the project. The contractor shall develop a presentation and provide sufficient porsonuel to represent the projects at the Engineering 410 Media Day at the end of the semester.

3.3.1.8.1 The contractor shall prepare a videotape (5-10 minutes) detailing the construction, operation, safety, maintenance, assembly, disassembly, storage and transportation of the Pottable Electric Cart Ramp. This video shall be displayed during Media Day and delivered to the user at the product aceeplance demonstration.

3.3.1.8.2 In addition to the Public Affairs Poster required by Contract Data Requirements List Number A0010 in the Engr 410 text, the contractor shall preparc a one-page summary of the project, including a photograph, in an hitml (web page) file. This file shall be stored in the $\mathrm{T} 6 \mathrm{~B}$ section directory on the $\mathrm{K}$ drive. 
3.3.1.9 Incentives -- The contractor may petition the govemment for incentive awards for enhancentents to the project such as, but not limited pickup truck), early milestone ramp with a conversion wan (in addition to a cost, or publication of news releapetions, el imination of subcontractor newspaper.

\subsubsection{SPECIFIC TECHNICAL REQUIREMENTS}

3.3.2.1 The electric cart ramp must support the weight of a 250 pound electric mobility cart plus a 200 pound adult. The contractor shall verify the weight of the type of electric mobility cart used by Ms McGregot.

3.3.2.2 The contractor slatl ensure the tamp meets the slope requirements of the Americans with Disabilities Act $(\mathrm{ADA})$, or in any case, meets the
slope requirements of the user.

3.3.2.3 The ramp shall telescope or fold or easily compact by some other manner to become approximately the size of a suitcase so it can be checked as luggage on board the aitlines. In any case, the compacted ramp shall not exceed the dimensions allowed by the airlines for a checked piece of iuggage. Appropriate latches or testraints shall be provided to cnsure the ramp remains in the compact configuration during transportation.

3.3.2.4 The weight of the ramp should not exceed 30 pounds and certainly shall not exced the airline limit for weight of a chocked piece of luggage.

3.3.2.5 It shail be safe and easy for one person to deploy and install the rump on the pickup truck. Sufficient locks, latches, braces, elc. shall be provided to ensure the ramp maintains a rigid configuration during use after installation.

3.3.2.6 The surface of the tamp shall meet the ADA requirements for a nonslip, good traction surface. In any case, the traction requirements of the uscr shall be met.

3.3.2.7 The width of the ramp shall safely accommodate the width of the standard 3-whel electric mobility cart used by Ms McGregor as well as the width of a standard manual wheelchair (not simultaneously).

"Proceedings of the 2004 American Society for Engineering

Education Annual Conference \& Exposition

Copyright (C2004, American Society for Engineering Education" 
3.3.2.8 The ramp must be designed for pickup trucks such as the Ford F-150, the Chevrolet 1500 , and the Toyota Tundra, or cquivalent sized pickups.

3.3.2.9 When in the compact configuration, the ramp shall have easily accessible carrying handles and/or wheels to facilitate the transportation of the ramp.

3.3.2.10 The ramp shall attach securely to the pickup truck to ensure the salety of the person on the ramp in the electric cart. The attachment shall withstand loads in the forward, rear, lateral, and vertical dircetions without becoming dislodged.

3.3.2.11 Reliability and Maintainability -- The lift must have a designed minimum service life or 10 ycars without replacement of any major components and require periodic maintenance at no less than 90 day intervals. Any components which are intended to receivo periodic maintenance must be designed for easy removal and teplacement with common hand tools.

\subsubsection{OTHER REQUIREMENTS}

\subsubsection{Management Control System}

\section{3,3.1,1 Time logs -}

3.3.3.1.1 The contractor shall appoint a designated individual who will EVERY LESSON collect the time (technical and non-technical) spent on the project since the last lesson by each of the individual contractors.

3.3,3.1.2 The timekeeper shall maintain the time log data in the class project notcbook and in a Microsoft Excel spreadsheet in the section folder on the $\mathrm{K}$ drive. The timekeoper shall produce reports and graphs from the spreadshect at times and in a format as requested by the govenment. For example, cvery 5 lessons (i.e., on Lsn 5, 10, 15, etc.) charts of cumulative tech timc, cumulative non-tech time, and cumulative total time spent on the project: 1) by the compary as a whole and 2) by each individuat contractor, shail be presented to the government.

3.3.3.2 Project Scherule. The contractor shall develop a project schedule using Microsoft Project, Prima Vera, or Sure Trak (3 project management softwares) to allow for frequent updates and changes, The contractor shail present the project schedule and charts at all briefings. 


\section{APPENDIX B \\ KEY AND RESULTS OF THE STUDENT COURSE CRITIQUES FOR ENGINEERING 410 ENGINEERING SYSTEMS DESIGN}

\section{KEY TO QUESTIONS ASKED ON THE CRITIQUE}

\section{SECTION FOR DIAGNOSTIC FEEDBACK TO THE INSTRUCTOR}

1. INSTRUCTOR ABILITY TO STIMULATE MY INTEREST WAS?

2. QUANLITY AND TIMELINESS OF FEEDBACK ON GRADED WORK WAS?

3. INSTRUCTOR'S ABILITY TO PROVIDE CLEAR, WELL ORGANIZED INSTRUCTION WAS?

4. INSTRUCTOR'S ABILITY TO PRESENT ALTERNATIVE EXPLAINATION WHEN NEEDED ?

5. INSTRUCTOR'S USE OF EXAMPLES AND ILLUSTRATIONS WAS?

6. VALUE OF QUESTIONS AND PROBLEMS RAISED BY INSTRUCTOR WAS?

7. INSTRUCTOR' KNOWLEDG OF THE COURSE MATERIAL WAS?

8. AS A MILITARY ROLE MODEL OR CIVILIAN PROFESSIONAL ROLE MODEL, MY INSTRUCTOR WAS?

9. ENCOURAGEMENT GIVEN STUDENTS TO EXPRESS THEMSELVES AND PARTICIPATE WAS?

10. INSTRUCTOR'S CONCERN FOR MY LEARNING WAS?

11. AVAILABILITY OF EXTRA HELP WHEN NEEDED WAS?

12. INSTRUCTOR'S ENTHUSIASM WAS?

\section{INFORMATION ABOUT THE CLASS}

13. COURSE ORGANIZATION WAS?

14. CLARITY OF COURSE OBJECTIVES AND REQUIREMENS WAS?

15. THE DEGREE TO WHICH THE COURSE MET ITS STATED OBJECTIVE WAS?

16. INTELLECTUAL CHALLENGE AND ENCOURAGEMENT OF INDEPENDENT THOUGHT WAS?

17. REASONABLENESS (DIFFICULTY AND AMOUNT) OF ASSIGNED WORK WAS?

18. EVALUATIVE AND GRADING TECHNIQUES (TESTS, PAPERS, PROJECTS, ETC.) WERE? 19. QUALITY AND USEFULNESS OF COURSE TEST(s) WERE?

\section{GENERAL EVALUATION}

20. THE COURSE AS A WHOLE WAS?

21 RELEVANCE AND USEFULNESS OF COURSE CONTENT WERE?

22. AMOUNT YOU LEARNED IN THE CLASS WAS?

23.THE INSTRUCTOR'S EFFECTIVENESS IN FACILITATING MY LEARNING IN THE COURSE WAS? 


\section{RESULTS OF STUDENT COURSE CRITIQUES FOR ENGINEERING 410 ENGINEERING SYSTEMS DESIGN}

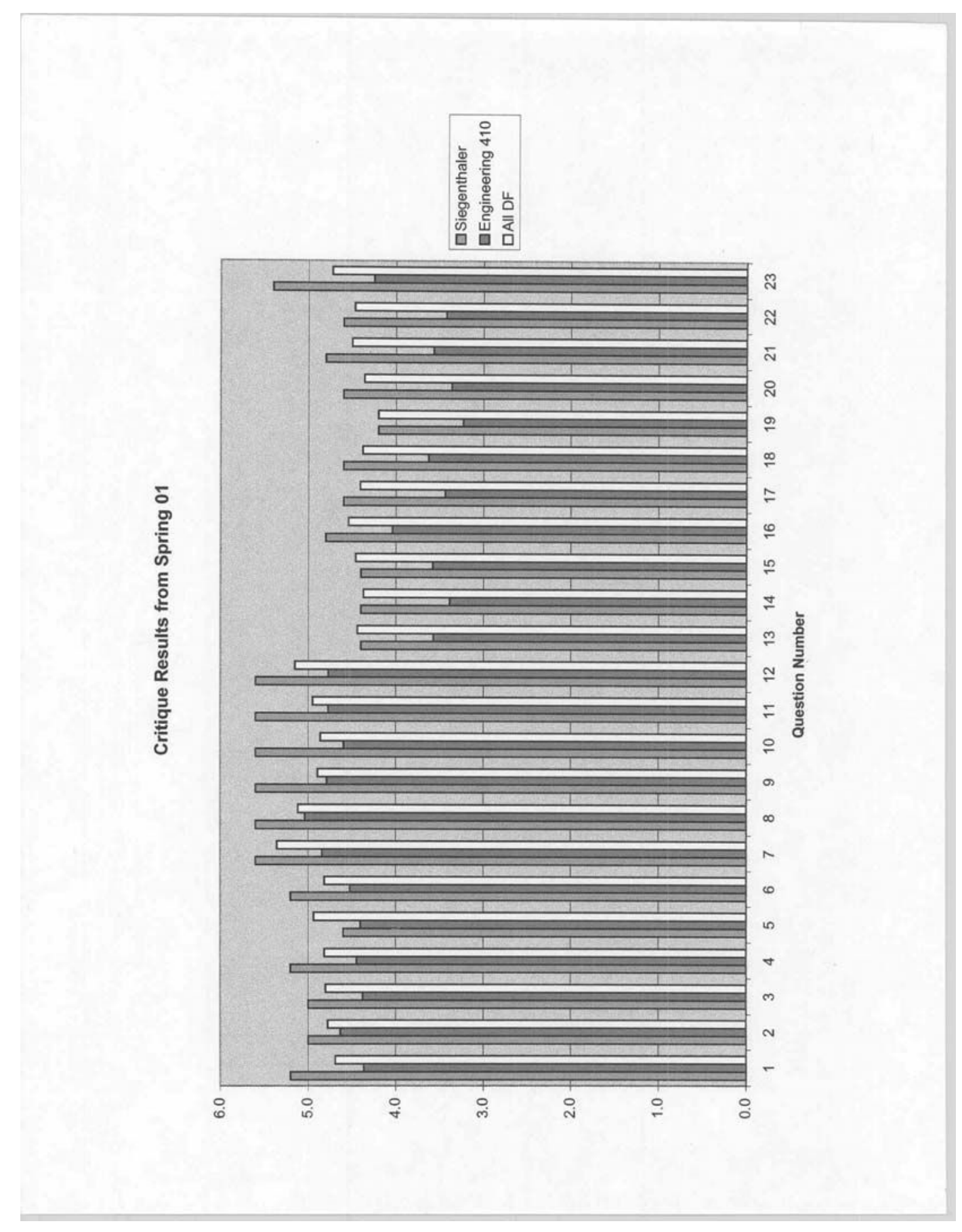

